Surface Water Pollution and its Control 
To my wife, without whose support and encouragement this volume would never have been completed 


\title{
Surface Water Pollution and its Control
}

\author{
K. V. Ellis \\ Lecturer in Environmental Health Engineering \\ University of Loughborough \\ with chapters by \\ G. White \\ Senior Lecturer in Resource Ecology \\ University of Loughborough \\ and \\ A. E. Warn \\ Regional Scientist (Regulation) \\ Anglian Water Authority, Huntingdon
}

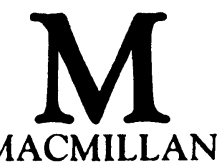


(C) K. V. Ellis, G. White and A. E. Warn 1989

Softcover reprint of the hardcover 1st edition 1989

All rights reserved. No reproduction, copy or transmission of this publication may be made without written permission.

No paragraph of this publication may be reproduced, copied or transmitted save with written permission or in accordance with the provisions of the Copyright, Designs and Patents Act 1988, or under the terms of any licence permitting limited copying issued by the Copyright Licensing Agency, 90 Tottenham Court Road, London W1P 9HE.

Any person who does any unauthorised act in relation to this publication may be liable to criminal prosecution and civil claims for damages.

First published 1989 by

THE MACMILLAN PRESS LTD

Houndmills, Basingstoke, Hampshire RG21 2XS

and London

Companies and representatives

throughout the world

ISBN 978-1-349-09073-0 ISBN 978-1-349-09071-6 (eBook)

DOI 10.1007/978-1-349-09071-6

A catalogue record for this book is available from the British Library.

Reprinted 1993 


\section{Contents}

$\begin{array}{ll}\text { Preface ix } & \text { ix }\end{array}$

Acknowledgements xiii

Part 1 Fundamentals 1

1. Parameters of Surface Water Quality and their Interpretation 3

Dissolved oxygen 3

The biochemical oxygen demand $\quad 8$

Chemical oxidation tests $\quad 18$

Total organic carbon $\quad 22$

Combined nitrogen 24

Phosphorus and phosphates $\quad 26$

Synthetic detergents $\quad 27$

Alkalinity 31

Acidity $\quad 36$

2. Introduction to Microbiology 38

Subdivision of micro-organisms $\quad 40$

$\begin{array}{ll}\text { The algae } & 40\end{array}$

The protozoa $\quad 44$

The fungi (yeasts and moulds) 48

The bacteria 51

The pleuro pneumonia-like organisms $\quad 57$

The Rickettsiae $\quad 58$

The viruses $\quad 58$

Sewage fungus $\quad 61$

3. The Biology of Surface Waters

by G. White 66

The rhithron-the major erosional region $\quad 76$

The potamon - the major depositional zone $\quad 79$

Biological indicators and pollution $\quad 82$

$\begin{array}{ll}\text { Freshwater fish and water quality } & 87\end{array}$ 


\section{Part 2 Water Pollution}

4. The Quality of Natural Waters 93

$\begin{array}{lr}\text { Toxicants in surface waters } & 97\end{array}$

$\begin{array}{lr}\text { Heavy metals in water } & 100\end{array}$

$\begin{array}{ll}\text { Pesticides in water } & 101\end{array}$

$\begin{array}{ll}\text { Ammonia in water } & 104\end{array}$

$\begin{array}{ll}\text { River water quality } & 109\end{array}$

5. De-oxygenation, Self-purification and Reaeration 119

$\begin{array}{ll}\text { River purification lakes } & 128\end{array}$

Water quality models $\quad 132$

Development from the basic Streeter-Phelps equation 134

Effects of nitrification $\quad 135$

$\begin{array}{ll}\text { The prediction of reaeration coefficients } & 137\end{array}$

Techniques for determining the reaeration coefficient 140

The effect of wind and rain on surface aeration 143

$\begin{array}{ll}\text { Rainfall and surface aeration } & 147\end{array}$

$\begin{array}{ll}\text { Reaeration at weirs } & 150\end{array}$

6. Water and Disease 154

Some water-borne infections (also water-washed) $\quad 156$

$\begin{array}{ll}\text { Water-based diseases } & 161\end{array}$

Water-related/insect vector diseases 165

Survival of pathogenic organisms in sewage effluents $\quad 167$

Bacterial indicators of faecal pollution $\quad 172$

$\begin{array}{ll}\text { Usefulness of indicator bacteria } & 177\end{array}$

7. Oil Pollution 182

The effects of oil on surface waters $\quad 184$

$\begin{array}{lr}\text { Identification of oils } & 187\end{array}$

$\begin{array}{ll}\text { Spillage prevention } & 189\end{array}$

Clean-up of oil spills 193

8. Temperature Effects and Thermal Pollution 208

Natural temperatures of surface waters $\quad 209$

Effect of temperature on aquatic life 211

$\begin{array}{ll}\text { Temperature and fish } & 214\end{array}$

$\begin{array}{lll}\text { Part } 3 & \text { Special Categories of Pollution } & 217\end{array}$

9. Eutrophication 219

Growth conditions and factors 223 
Predicting variations in parameters and conditions 225

$\begin{array}{ll}\text { Control of eutrophication } & 228\end{array}$

10. Acid Precipitation and its Effect on Surface Waters 235

$\begin{array}{ll}\text { Acid drainage from mines } & 249\end{array}$

11. Storm Sewage Discharges and Urban Surface Water Run-off 253

Combined and separate sewerage systems 255

Storm sewage discharges from combined systems 258

The design and operation of storm sewage overflows 262

$\begin{array}{ll}\text { Storm-water run-off in urban areas } & 268\end{array}$

$\begin{array}{llr}\text { Part } 4 & \text { Towards Pollution Control } & 277\end{array}$

$\begin{array}{ll}\text { 12. Legislation } & 279\end{array}$

British water pollution control legislation $\quad 281$

Common law 296

Control of water pollution in the USA 297

13. Operation of a Surface Water Pollution Control Organisation 305

$\begin{array}{ll}\text { Developing countries } & 318\end{array}$

14. River Quality Modelling

by A. E. Warn $\quad 322$

$\begin{array}{ll}\text { Introduction } & 322\end{array}$

Mathematical models $\quad 322$

Background and history $\quad 324$

$\begin{array}{ll}\text { Chemical kinetics } & 327\end{array}$

Water quality standards $\quad 331$

The mass balance error $\quad 334$

Combining distribution methods $\quad 335$

Significance of the mass balance error $\quad 336$

Catchment models $\quad 336$

Structure of the calculations $\quad 337$

Sampling error $\quad 338$

Using a catchment model $\quad 340$

Calibration $\quad 341$

$\begin{array}{ll}\text { Conclusions } & 342\end{array}$

References (and Bibliography) $\quad 344$

$\begin{array}{lr}\text { Index } & 367\end{array}$ 


\section{Preface}

With surface water control having been, either directly or indirectly, so much a part of my life for nearly thirty years, I have tended to develop a line of thinking and an assemblage of ideas on the subject which cannot be adequately communicated-even by a university teacher-other than through the medium of a book. A book is perhaps the safety valve which releases the pressure of accumulated ideas and concerns which have been quietly (or, perhaps, not so quietly) fermenting for years under the restraints imposed by an ordered teaching programme which only infrequently confronts this subject directly. As a result, a book has been produced which I trust reflects to some extent my continuing commitment to, and concern for, the control of pollution in surface waters.

Few people associated with the protection of surface waters-or of the environment in general-can fail to become intensely involved with the subject. This is both a good thing and a bad thing. A person who is unable to sense the wonder and beauty, the infinite variety and the continually fresh appeal of natural waters, and who is not held in awe by the multitudinous forms of ascending and descending levels of life in the natural chain, cannot be fit to think of and plan for rivers, other than as the natural drains of the landscape. Conversely, a too close involvement by the professional is likely to result in a clouded judgement and in decisions taken that are motivated more by emotion than by reason. Such an approach must frequently be counter-productive. As a result the surface water pollution control specialist, in common perhaps with the historian, finds himself held in a productive tension, continually pulled between the attraction of emotional attachment and that absolute necessity for a scientist - an objective overview. I make no apologies for my involvement but hope that the required detachment also shows through. I also trust that this book reflects the high professionalism of so many of those in the British water industry in particular from whom I learned my trade.

Not that this book is actually the one that I intended to write. Initially the intention was to produce a volume concerned with the techniques of waste water treatment. However, it did not seem possible to write such a book without a section which attempted to fit the necessity for waste water treatment into its proper context in the broader field of water pollution control. This broader field, which has always proved to be so absorbing, demanding and satisfying to me, eventually took over completely. As a result, the more directly technical problems of waste water treatment will now have to be dealt with in a second 
volume which will be designed to complement the wider perspective of the first. For the present volume I must admit my debt to the now near-classic of surface water pollution control-Louis Klein's River Pollution of some thirty years ago-which was for so long a source of knowledge and insight to those arriving, uninformed, in the industry, and which I hope that this work will somehow emulate.

The book is produced for the growing surface water pollution control industry world-wide. It is written in particular for graduates of more restricted disciplines such as chemistry, engineering and geography, etc. who are entering into the wide field of surface water pollution control lacking a sufficient background knowledge of all that this subject encompasses. It is also very specifically aimed at those administrators who are increasingly becoming involved in the direction of affairs without ever having been fortunate enough to have had experience in the 'field', and hence have not been able to develop the essential 'feel' for the subject. Very importantly, it is also produced for students-postgraduate students in particular-whose courses are concerned directly or indirectly with environmental management. It will be especially useful to civil engineering students involved in those sections of public health engineering related to water pollution control. It will, in addition, be directly useful to students of geography and of environmental sciences whose specialist options or courses relate directly to this subject. Also very importantly, this book has been written with the concerns of the developing world in mind. Much of my work over recent years has been involved with aspects of water pollution control in the developing world and the particular problems and requirements of those countries have provided much of my motivation.

The early chapters of this book reflect my conviction that no engineer, scientist or administrator can effectively appreciate the art of surface water pollution control without a basic knowledge of microbiology and of the parameters (determinands) by which the quality of surface water is measured. It is, after all, the micro-organisms which contribute so much to the selfpurification of streams as well as representing, as pathogens, one of the greatest problems of pollution associated with surface water; and without an understanding of the parameters of river quality and of their inter-relationships the concept of quality control is meaningless. Similarly, without a knowledge of the biology of surface waters, measures taken to protect stream life can be at best misguided and at worst futile.

The book continues by investigating specific forms of surface water pollution and their control. The specific forms of pollution investigated, while not necessarily being all-embracing, are those which in my experience are of major importance. The concept of water and disease is perhaps of particular importance in the context of the developing world situation, but even in the United Kingdom the problems of health in relation to polluted surface waters and recreation must assume a higher profile in the future. The major problem of 
eutrophication continues to exercise the imagination and ingenuity of many of those concerned with surface water pollution. To these problems there is no easy and cheap solution, but it is necessary that those involved should be fully informed as to the difficulties and how they can be prevented or overcome. Acid precipitation must now also be accepted by all, including governments, as being of major importance as a source of extensive surface water pollution in many parts of the world. This is perhaps one of the least understood but most important aspects of modern water pollution control in the developed world and as its effects continue to spread the concern associated with it amongst water pollution control specialists must be matched by an understanding of its sources, development, results and control.

Throughout the book a positive effort has been made to represent pollution and self-purification in as non-mathematical a form as is possible. This is not always easy, nor in several contexts can it be considered as being totally advisable. However, particularly when discussing self-purification, it is possible to become insulated in a web of mathematical symbols which while being satisfying to the narrow specialist, often fails to give to those seeking a broader view a meaningful understanding of what occurs. Even Dr Warn's excellent chapter on River Quality Modelling is in a form which, while not lacking in precision, is readily comprehensible by all.

Legislation is obviously the keystone by which all pollution control endeavours may succeed or fail. It would have been interesting to have been able to review constrasting legislation from around the world, but that would have been a too demanding and perhaps confusing task for one chapter, so it was necessary to be content with a review of the development of the appropriate legislation in the United Kingdom and the USA. As it is, the review of water pollution control legislation in these two countries permits the appreciation of the development of control legislation by two quite different routes operating through two largely distinct traditions. The chapter should be of special value to those contemplating the production of adequate legislation in the developing world. One is presented with a choice of styles and emphases from which a form of legislation appropriate to any individual developing country could be formulated.

In all countries in which sewered sanitation and industry are being developed, the need is for adequate, appropriate and enforceable legislation together with an organisation which can apply that legislation, without fear or favour, and yet with imagination and tolerance. I trust that the chapter dealing with the operation of a water pollution control organisation will provide some guidelines for those involved in setting up such an organisation in countries in which no effective administration of water pollution control legislation presently exists.

River quality modelling has grown over recent years to be a near essential skill for the control of complex river pollution problems. It is fortunate that one of the leading specialists in this demanding field should have been able to 


\section{xii Preface}

contribute a chapter on this subject. This chapter provides an informed and informative insight, to what can be a very involved topic, to all who wish either to begin or to further develop their involvement with it.

Finally I trust that the book will provide insight-and perhaps some pleasure too-to those who read it and that they will derive some benefit by increasing their knowledge of the wide subject of surface water pollution control. Despite the labour involved, it has been, on the whole, a pleasure to write and I hope that others-perhaps for a variety of reasons-will be able to share this pleasure.

Loughborough, 1988

K.V.E. 


\section{Acknowledgements}

The author wishes to express his thanks to the many people in the water industry who willingly provided information and advice. In particular he would like to thank Mr. Desmond Hammerton, the Director of the Clyde River Purification Board, Dr. G. A. Best, the Freshwater Survey Officer and all the staff at Rivers House who provided advice. In addition he would like to thank Mr. Eric Harper, Chief Scientific Officer of North West Water, and Mr. Ken Guiver, the Chief Scientific Officer of Southern Water, for allowing him to pick their brains. Thanks are also due to Mrs. Sue Ball for many of the diagrams. 